\title{
Investigation of the Relationship between the Motor Unit Number Estimate (MUNE) and the Mean Slope of the Stimulus-Response (SR) Curve of the Compound Muscle Action Potential (CMAP) Scan
}

\author{
Imran Göker ${ }^{1 *}$ \\ 1* Istanbul Arel University, Faculty of Engineering and Architecture, Departmant of Biomedical Engineering, İstanbul, Turkey, (ORCID: 0000-0000-0000-0000), \\ imrangoker@arel.edu.tr
}

(First received 20 February 2021 and in final form 28 May 2021)

(DOI: 10.31590/ejosat.803710)

\begin{abstract}
ATIF/REFERENCE: Göker, İ. (2021). Investigation of the Relationship between the Motor Unit Number Estimate (MUNE) and the Mean Slope of the Stimulus-Response (SR) Curve of the Compound Muscle Action Potential (CMAP) Scan. European Journal of Science and Technology, (25), 451-456.
\end{abstract}

\begin{abstract}
Objective: The goal of this study is to elicit the relationship between the MUNE and the Mean Slope of the SR Curve of the CMAP Scan. Introduction: MUNE is used to diagnose and to monitor the Neuromuscular Disorders. CMAP Scan is a neurophysiological method based on the gradual stimulation of motor neurons and on recording their responses. As a result, a Stimulus-Response (SR) curve is plotted to study the progress of these diseases. In healthy subjects, SR curve is in the sigmoid form. As Motor Unit (MU) loss takes place, higher stimulus intensities are required in CMAP Scan. In addition, the shape of the SR curve becomes different form rather than sigmoid. This affects the slope of the SR curve. Therefore, a new more integrative variable called Mean Slope can be defined which might be correlated with MUNE. Material and Methods: Motor neuron groups including 5- to-300 axons were constituted via a simulation software and they were stimulated incrementally with currents from 0 to $99 \mathrm{~mA}$. . The voltage differences were computed by using the CMAPs being the responses in the SR curve. The average of all slopes corresponding to each voltage differences was computed to find the Mean Slope. The correlation between MU number the Mean Slope was investigated statistically. Results and Discussion: The coefficient of determination and the Pearson correlation coefficient between MU number and the Mean Slope were found as 0.9974 and 0.999 respectively. A linear relationship between MU number and the Mean Slope was suggested. Conclusion and Recommendation: The mean slope can be taken into account as a new feature while building mathematical models for the MUNE methods. Besides, new variables in conjunction with the slope of the SR curve might be defined in future studies..
\end{abstract}

Keywords: Compound Muscle Action Potential (CMAP) Scan; Motor Unit Number Estimate (MUNE); Neuromuscular Diseases; Stimulus-Response Curve; Motor Unit Potential.

\section{Motor Ünite Sayısı Kestirimi (MÜSK) ve Birleşik Kas Aksiyon Potansiyeli (BKAP) Taraması Uyaran-Yanıt (UY) Ĕgrisinin Ortalama Eğimi arasındaki İliş̧inin Araştırılması}

$\ddot{O} z$

Amaç: Bu çalışmanın amacı Motor Ünite Sayısı Kestirimi (MÜSK) ile Birleşik Kas Aksiyon Potansiyeli (BKAP) Taraması UyaranYanıt (UY) Eğrisinin Ortalama Eğimi arasındaki ilişkiyi ortaya koymaktır. Giriş: Motor Ünite Sayısı Tahmin (MÜSK) nöromüsküler hastalıkların tanısını koymak ve bu hastalıkların takibi amaçlı olarak kullanılmaktadır. BKAP Taraması motor nöronların kademeli olarak uyarılması ve bunların yanıtlarının kaydedilmesi esasına dayanan bir nörofizyolojik yöntemdir. Buna bağlı olarak, bu hastalıkların seyrini incelemek üzere bir Uyaran-Yanıt (UY) eğrisi de çizdirilmektedir. Sağlıklı bireylerde, UY eğrisi sigmoid bir eğri şeklindedir. Motor Ünite (MÜ) kaybı meydana geldikçe BKAP taramasında daha yüksek şiddette uyarımlara gerek duyulmaktadır.

* Corresponding Author: imrangoker@ arel.edu.tr 
Ayrıca, UY eğrisinin şekli sigmoidden ziyade farklı bir şekle dönüşmektedir. Bu durumlar UY eğrisinin eğimini de etkilemektedir. Bu nedenle, MÜSK ile ilişkili olabilecek Ortalama Eğim olarak adlandırılabilecek daha bütüncül yeni bir değişken tanımlanabilir. Yöntem ve Gereçler: Bir simülasyon yazılımı ile, 5 ila 300 akson içeren motor nöron grupları oluşturuldu. Bu motor nöronlar kademeli olarak 0'dan 99 mA'e kadar giderek artan şiddette uyarıldılar. UY eğrisindeki yanıtlar olan BKAP değerlerinden faydalanılarak voltaj farkları hesaplandı. Her bir voltaj farkına karşılık gelen eğimlerin ortalama değerleri Ortalama Eğim değerini bulmak üzere hesaplandı. MÜ sayısı ile Ortalama Ĕ̆im arasında bir ilişki olup olmadığı istatistiksel olarak araştırıldı. Bulgular ve Tartışma: MÜ sayısı ile Ortalama Eğim arasındaki belirleme katsayısı ve Ortalama Eğim sırasıyla 0,9974 ve 0,999 olarak bulundu. Buna bağlı olarak, MÜ sayısı ile Ortalama Eğim arasında doğrusal bir ilişki olabileceği düşünüldü. Sonuç: Ortalama Eğim, MÜSE yöntemleri için matematik modeller oluşturulurken yeni bir öznitelik olarak göz önünde bulundurulabilir. Bunun yanı sıra, gelecek çalışmalarda, UY eğrisinin eğimi ile bağlantılı olabilecek yeni parametreler de tanımlanabilir..

Anahtar Kelimeler: Birleşik Kas Aksihyon Potansiyeli (BKAP) Taraması, Motor Ünite Sayısı Kestirimi (MÜSK), Nöromüsküler Hastalıklar, Uyaran-Yanıt Eğrisi, Motor Ünite Potansiyeli.

\section{Introduction}

Motor Unit Number Estimate (MUNE) is a quantitative method being developed to determine the number of axons approximately as much as possible. This method which is related the electrophysiological evaluation of the number axons innervating a muscle or a muscle group and representing the motor units (MU) in these muscles is utilized to monitor the neuromuscular diseases and to assess MU losses (Daube, 1995). In this method, the stimulus intensity applied to a motor nerve is gradually increased above a threshold value and the responses to these stimuli are recorded (McCommas, 1995; McCommas et al., 1971)..

One of the electrophysiological method utilized in diagnosing Neuromuscular Disorders is the Compound Muscle Action Potential (CMAP) Scan. It is practiced by recording the responses of incrementally stimulated motor neuron (Henderson et al.. 2006). These responses are graphically represented by the stimulus-response (SR) curve (Henderson et al.. 2006; Maathuis et al., 2011. Some studies that utilized CMAP Scan for estimating Motor Unit Number have been previously conducted (Bostock, 2016).
For healthy individuals, SR curve is represented in sigmoid form as in Figure 1. The purpose of this study is to investigate the relationship between the Motor Unit Number Estimate (MUNE) and the Mean Slope of the SR Curve of the CMAP Scan being the average of the successive incremental slopes. The slope of the linear portion of the SR curve depends on the axonal excitability of the MUs. As the number of the excited MUs which contribute also to CMAP Scan increases with the increasing stimulus intensities, the slope becomes steeper. On the other hand, as the MU loss occurs, this slope reduces becoming less steep (Araújo et al. 2015). In case of severe MU loss, the sigmoid form of the SR curve changes as shown in Figure 2. Therefore, the slope of the SR curve is less significant and a more integrative measure is required to estimate the number of MU being able to be recruited with the increasing stimulus intensities. The average value of the incremental slopes computed via the successive voltage differences and the stimulus intensities might be considered as indicator for MUNE. Moreover, negative incremental slopes and those with zero values emerging from the alternations might be taken into account.

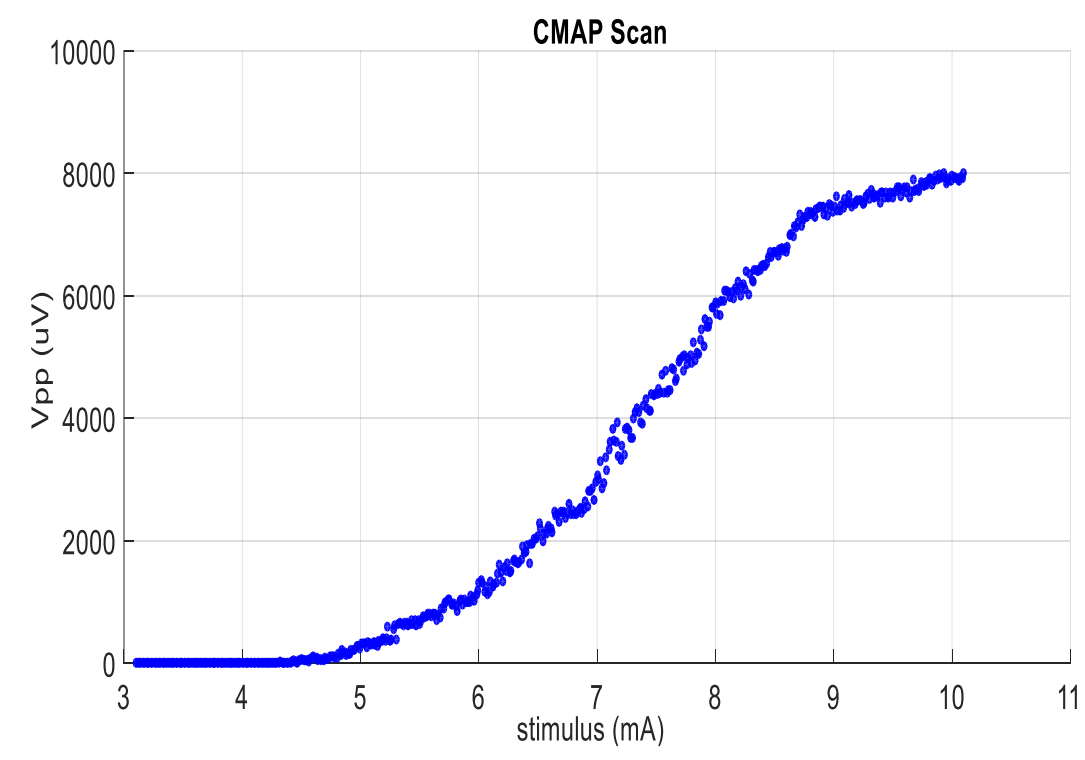

Figure 1. The CMAP Scan (SR curve) of a healthy individual 


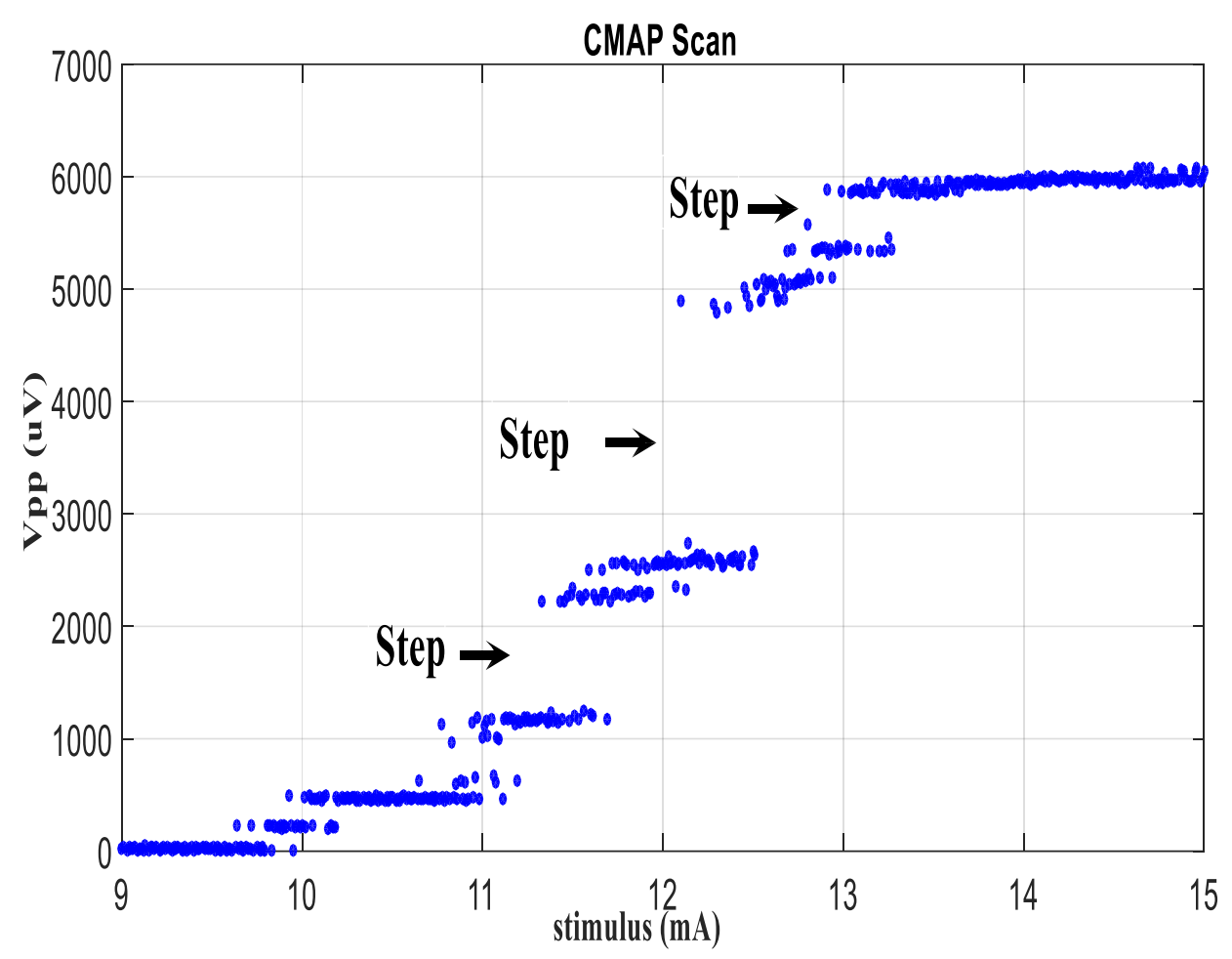

Figure 2. The CMAP Scan (SR curve) for a case with Anterior-Horn Disease (Steps are demonstrated with arrows)

\section{Material and Method}

\subsection{Building Data Sets}

Data sets were built by means of a simulator software ((Motor Nerve Conduction Studies (MNCS) Neurography Simulator version 2.4, Keypoint Club, Uppsala, Sweden).

Motor neuron groups containing axons in various numbers ranging from 5 to 300 were constituted via the simulator.

Each of these groups were stimulated by 0- to $99-\mathrm{mA}$ currents from the distal positions of with 1-mA increments. Five distinct cases were built for each group.

The interface of the simulator is demonstrated in Figure 3. It enables the user to monitor the waveforms of CMAP traces. These were recorded in ".txt" format via "export" menu of the simulator into a folder in the root directory to be processed by MATLAB Code built for data analysis.

\subsection{Computation of Mean Slope}

CMAPs are the peak-to-peak voltages Vpp of the waveforms of CMAP traces. They represent the responses to stimuli on the vertical axis of SR-curve. In determining the incremental slopes, initially, the voltage differences $\Delta \mathrm{Vpp}$ and the differences of successive stimuli $\Delta \mathrm{S}$ should be calculated as follows;

$$
\begin{aligned}
& \Delta V_{p p}(i)=V_{p p}(i)-V_{p p}(i-1) \\
& \Delta S(i)=S(i)-S(i-1)
\end{aligned}
$$

In equation (1) and (2), $\mathrm{i}$ is the index of the corresponding stimulus.

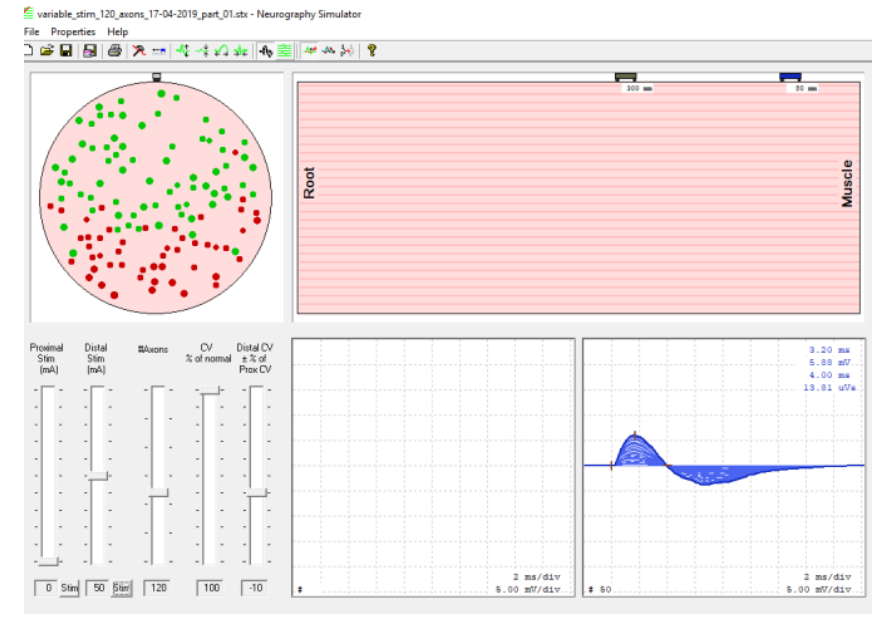

Figure 3. The CMAP responses generated by the incremental stimulation of the Motor Neuron in the Simulator. 


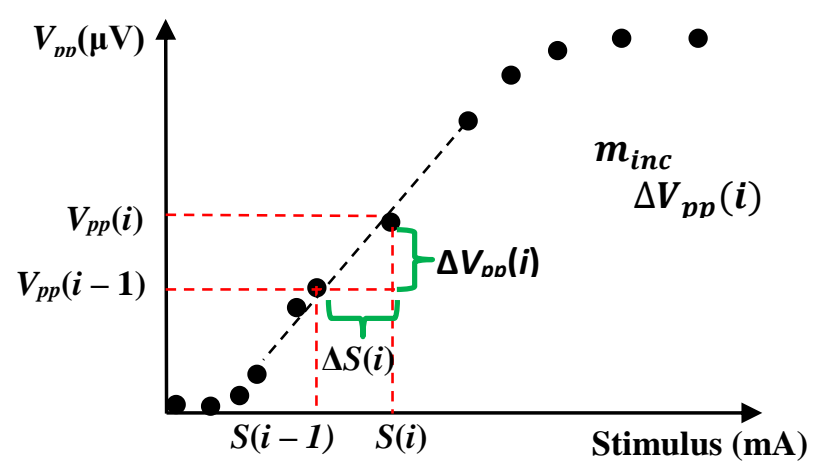

Figure 4. Representation of the incremental slope $m_{\text {inc }}$ in a CMAP Scan

The incremental slope minc being shown in Figure 4, may be calculated as follows;

$m_{\text {inc }}(i)=\frac{\Delta V_{p p}(i)}{\Delta S(i)}$

Total slope which is the sum of the incremental slopes is given as follows;

$m_{\text {total }}=\sum_{i=1}^{N} m_{\text {inc }}(i)$

The mean slope can be computed as follows;

$\bar{m}=\frac{m_{\text {total }}}{N}=\frac{\sum_{i=1}^{N} m_{\text {inc }}(i)}{N}$

where $N$ is the responses.

\subsection{Program Codes for Computations}

A MATLAB ${ }^{\circledR}$ (Version R2015a)( Mathworks, USA) Code was established to use the exported CMAP data from the simulation software in ".txt" format. The peak-to-peak voltages for each CMAP trace and the voltage differences between these consecutive peak-to-peak values and the differences of consecutive stimulus intensities were calculated through this code. The calculation of the increment means, the total mean and the mean slopes was also accomplished via this code. The flowchart of the program codes are shown in Figure 5.

\subsection{Statistical Analysis of the Data}

The relationship between the Number of MUs and the Mean Slope was investigated by computing the correlation coefficient. SPSS Software Package (IBM ${ }^{\circledR}$ SPSS Statistics ${ }^{\circledR}$ v.22.0, SPSS, Inc., Chicago, IL) was utilized for this statistical analysis.

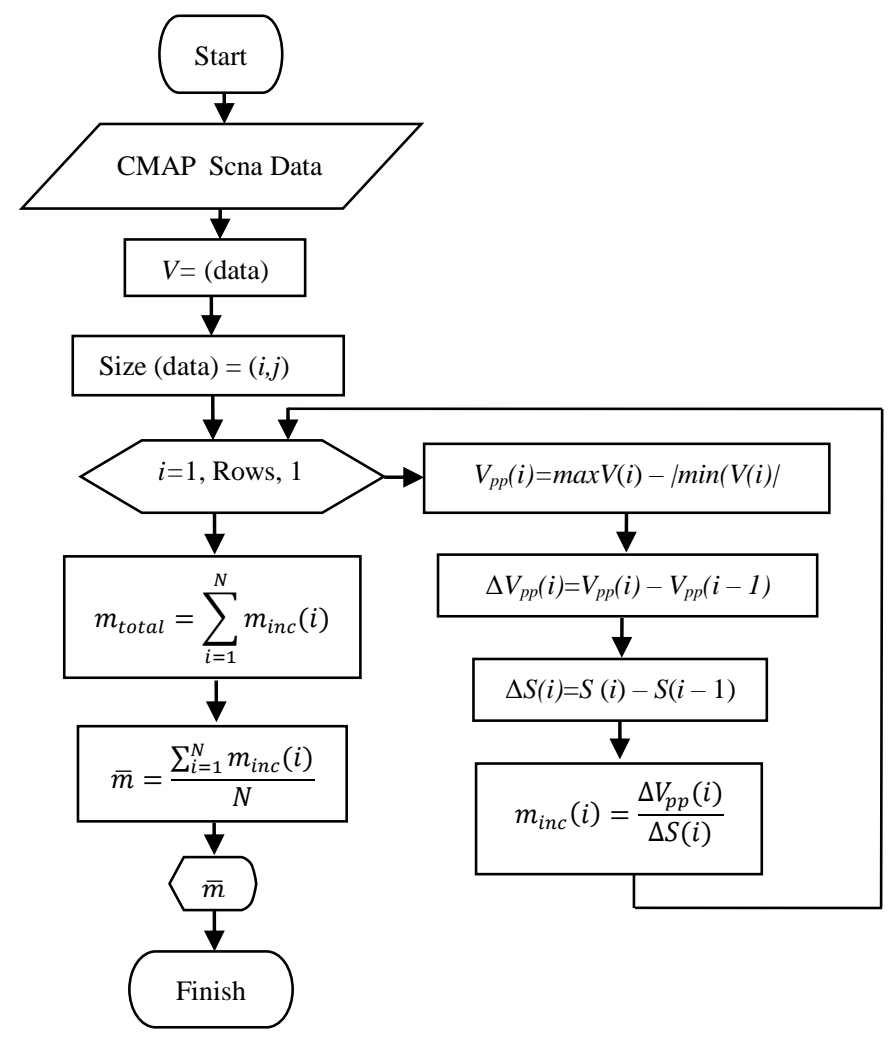

Figure 5. The Flow-Chart of the Program Code for computations 
European Journal of Science and Technology

Table 1. Mean Slopes and Numbers of Axons

\begin{tabular}{|c|c|}
\hline Number of Simulated Axons $\left(n_{\text {axon }}\right)$ & Mean Slope $(\bar{m})($ Mean \pm SD $)$ \\
\hline 5 & $0.0086 \pm 0.0037$ \\
\hline 10 & $0.0140 \pm 0.0025$ \\
\hline 15 & $0.0209 \pm 0.0042$ \\
\hline 20 & $0.0271 \pm 0.0035$ \\
\hline 25 & $0.0354 \pm 0.0025$ \\
\hline 30 & $0.0452 \pm 0.0089$ \\
\hline 35 & $0.0503 \pm 0.0067$ \\
\hline 40 & $0.0566 \pm 0.0040$ \\
\hline 45 & $0.0688 \pm 0.0078$ \\
\hline 50 & $0.0710 \pm 0.0090$ \\
\hline 55 & $0.0773 \pm 0.0051$ \\
\hline 60 & $0.0811 \pm 0.0088$ \\
\hline 65 & $0.0895 \pm 0.0119$ \\
\hline 70 & $0.1026 \pm 0.0123$ \\
\hline 75 & $0.1096 \pm 0.0059$ \\
\hline 80 & $0.1122 \pm 0.0030$ \\
\hline 85 & $0.1235 \pm 0.0129$ \\
\hline 90 & $0.1291 \pm 0.0125$ \\
\hline 95 & $0.1536 \pm 0.0244$ \\
\hline 100 & $0.1514 \pm 0.0110$ \\
\hline 105 & $0.1512 \pm 0.0091$ \\
\hline 110 & $0.1595 \pm 0.0146$ \\
\hline 115 & $0.1637 \pm 0.0059$ \\
\hline 120 & $0.1625 \pm 0.0072$ \\
\hline 125 & $0.1780 \pm 0.0011$ \\
\hline 130 & $0.1849 \pm 0.0000$ \\
\hline 135 & $0.1880 \pm 0.0000$ \\
\hline 140 & $0.1921 \pm 0.0000$ \\
\hline 145 & $0.2066 \pm 0.0081$ \\
\hline 150 & $0.1846 \pm 0.0000$ \\
\hline 155 & $0.2190 \pm 0.0168$ \\
\hline 160 & $0.2373 \pm 0.0123$ \\
\hline 165 & $0.2320 \pm 0.0082$ \\
\hline 170 & $0.2435 \pm 0.0276$ \\
\hline 175 & $0.2541 \pm 0.0098$ \\
\hline 180 & $0.2594 \pm 0.0071$ \\
\hline 185 & $0.2561 \pm 0.0157$ \\
\hline 190 & $0.2803 \pm 0.0075$ \\
\hline 195 & $0.2806 \pm 0.0163$ \\
\hline 200 & $0.2795 \pm 0.0162$ \\
\hline 205 & $0.2972 \pm 0.0263$ \\
\hline 210 & $0.2991 \pm 0.0147$ \\
\hline 215 & $0.3098 \pm 0.0142$ \\
\hline 220 & $0.3255 \pm 0.0134$ \\
\hline 225 & $0.3269 \pm 0.0172$ \\
\hline 230 & $0.3239 \pm 0.0098$ \\
\hline 235 & $0.3471 \pm 0.0190$ \\
\hline 240 & $0.3483 \pm 0.0188$ \\
\hline 245 & $0.3498 \pm 0.0231$ \\
\hline 250 & $0.3596 \pm 0.0186$ \\
\hline 255 & $0.3706 \pm 0.0212$ \\
\hline 260 & $0.3777 \pm 0.0111$ \\
\hline 265 & $0.3850 \pm 0.0070$ \\
\hline 270 & $0.3977 \pm 0.0117$ \\
\hline 275 & $0.3970 \pm 0.0188$ \\
\hline 280 & $0.3928 \pm 0.0227$ \\
\hline 285 & $0.4137 \pm 0.0153$ \\
\hline 290 & $0.4205 \pm 0.0158$ \\
\hline 295 & $0.4220 \pm 0.0106$ \\
\hline 300 & $0.4326 \pm 0.0215$ \\
\hline
\end{tabular}




\section{Mean Slopes vs Numbers of Simulated Axons}

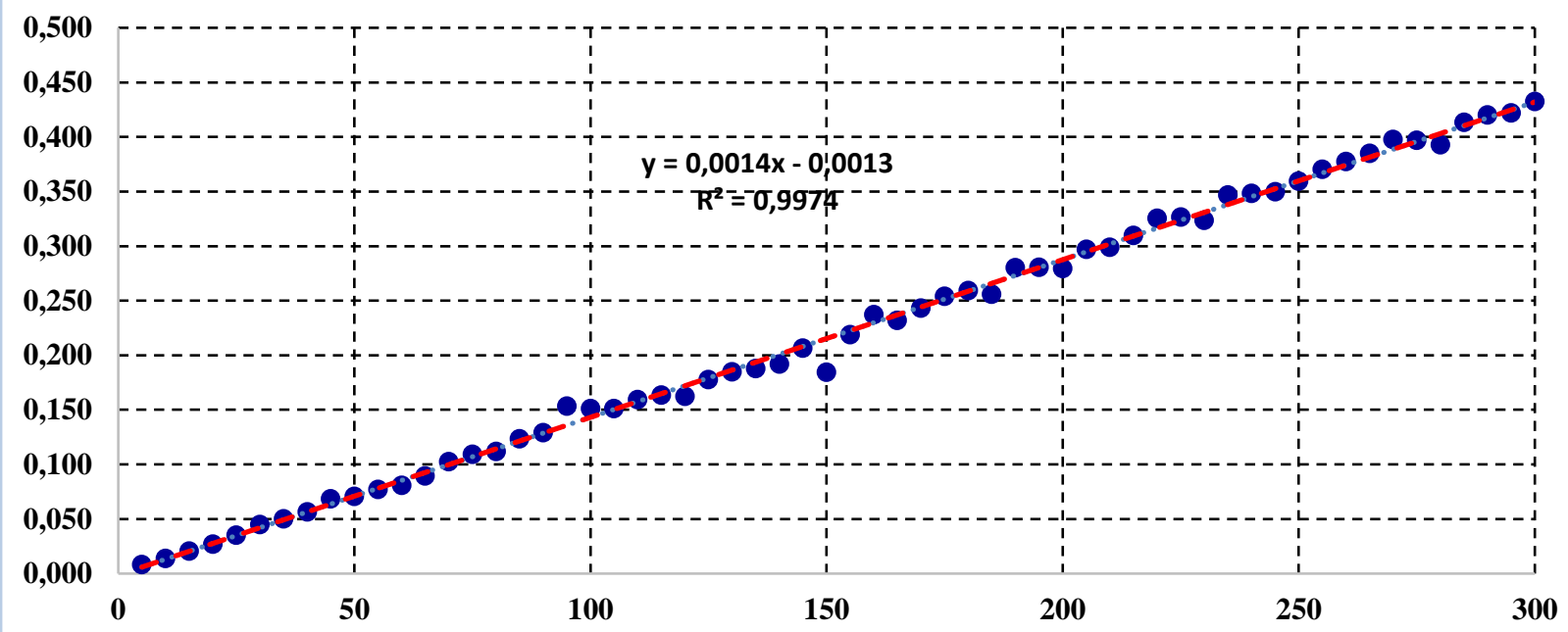

Figure 6. The plot of mean slope vs number of axons.

\section{Results and Discussion}

The mean slope values calculated from the CMAP Scan data being generated in the simulation software are presented in terms of number of axons in Table 1.

In addition, the plot of mean slope vs the number of axons is shown in Figure 6.

In Figure 6, it is observed that the majority of the data are accumulated nearby a regression line. Furthermore, the Coefficient of Determination was found as $0.9974\left(\mathrm{R}^{2}=0.9974\right)$.

When the relationship between the Number of Axons and the Mean Slope was analyzed statistically, the Pearson Correlation Coefficient was found as $0.999(\rho=0.999)$.

When the data presented in Figure 6 are tackled, the linear relationship can be observed in by inspection. This relationship can be also indicated via the Coefficient of Determination $(\mathrm{R} 2=0.9974)$. This is supported also via Pearson Correlation Coefficient $(\rho=0.999)$.

\section{Conclusions and Recommendations}

In conclusion, the mean slope can be taken into account while building mathematical models for the MUNE methods. Moreover, some other new variables in conjunction with the slope of the SR curve might be defined in future studies in order to build more accurate mathematical models for the computation of MUNE.

\section{Acknowledgment}

I would like to present my gratitude to my deceased spouse Iryna NAUMCHIK GÖKER who had been always supporting me especially during this study.

\section{References}

Araújo T., Candeias R., Nunes N., \& Gamboa H. (2015) Evaluation of Motor Neuron Excitability by CMAP Scanning with Electric Modulated Current Neuroscience Journal, 2015, 5 pages, epub 2015.
Bostock, H. (2016) Estimating motor unit numbers from a CMAP scan Muscle and Nerve, 53(6), 889-896.

Daube, J. R (1995) Estimating the number of motor units in a muscle Journal of Clinical Neurophysiology 12(6), 585594.

Henderson, R. D., Ridall G. R., Pettitt, A. N., McCombe, P. A., \& Daube, J. R. (2006) The Stimulus-Response Curve and Motor Unit Variability in Normal Subjects And Subjects with Amyotrophic Lateral Sclerosis Muscle and Nerve, 34 (1), 34-43.

Maathuis, E. M., Drenthen, J., Visser, G. H., \& Blok, J. H. (2011) Reproducibility of the CMAP scan Journal of Electromyography and Kinesiology, 21(3), 433-437.

McCommas, A. J. (1995) Motor Unit Estimation: Anxieties and Achievements Muscle and Nerve 18 (4), 369-379.

McComas J., Fawcett P. R. W., Campbell, M. J., \& Sica, R. E. P. (1971) Electrophysiological estimation of the number of motor units within a human muscle Journal of Neurology, Neurosurgery, and Psychiatry 34 (2), 21-131. 